\title{
TRANSFER AND INTEGRATION FOREIGN LITERATURES IN NATIONAL CONTEXTS
}

\author{
Guesteditors:
}

Els Andringa, Sophie Levie 


\section{Transfer and Integration Foreign Literatures in National Contexts}

Scholars of comparative literature have studied for a long time the border crossing of literature. During the early 1970s, scholars working in what came to be known as reception aesthetics have laid the theoretical groundwork for research on processes involving the interaction of works and audiences, canonization, and changes in literary values and functions. Intercultural exchange was not at the core of these incisive explorations, but this changed in the 1980s, when a number of transnational reception studies began to appear. This is when intraliterary dynamics, such as poetical influence, intertextual and medial transformation, or the circulation of motifs and ideas became again the object of studies. Some of these studies also include extraliterary factors, such as the impact of the book market and the role of changing political, ideological, and social circumstances. An impressive collection of comparative studies has come together in the series The Reception of British and Irish Authors in Europe', which presents longitudinal reception research and cross sections of transnational reception.

In tandem with these developments within reception studies, new disciplines have emerged over the last two decades, paying special attention to the migration and mobility of literary products. Translation studies, the sociology of culture, and book history have all become subdisciplines, each with specific research questions and methods. They have opened up new avenues and have drawn attention to a wide range of factors that had so far been neglected. Comparative studies, which, until recently, focused chiefly on works, authors, genres, and periods, often from the perspective of a single language, had ignored bilateral conditions and the interplay of various literary fields.

This special issue focuses on processes of literary transfer and transnational reception. Three strands of theoretical-descriptive research are paramount for the work presented here: Pierre Bourdieu's sociology of the literary field, Itamar EvenZohar's polysystem theory, and concepts taken from book history and translation studies.

Sociological approaches originating from Bourdieu's work reveal the powerful impact of social forces, such as the struggle for recognition, intellectual power, and identity, in what has been respectively called the cultural or literary field. This type of research focuses on the role of social mechanisms, laying bare the strategies of cultural institutions. Translation and international reception studies have lately taken advantage of these sociological insights, which had initially been confined to

1 The Athlone Critical Traditions. The Reception of British and Irish Authors in Europe, published by Thoemmes Continuum and coordinated by Elinor Shaffer, have been appcaring from 2002 onwards. For further information, see www.clarehall.cam.ac.uk/rbae. 
a single nation. Thus, Joseph Jurt was amongst the first to apply and adjust Bourdieu's concepts to the study of transnational reception. ${ }^{2}$ His contribution to this issue offers a compact overview of aspects in Bourdieu's work that bear on the international transfer of culture and ideas. These include, as Pascale Casanova argues, the struggle of 'minor literatures' for international acclaim; the status of national languages and cultures; the role of a cultural vacuum in a national context; and the ambition to establish or confirm national identity in an international space. ${ }^{3}$ The special issue of Actes de la recherche en sciences sociales (2002, edited by Johan Heilbron and Gisèle Sapiro) marks a breakthrough in the sociological approach to translation and transnational reception. It contains articles addressing, among others, the 'vocation' and profession of translating, the position of translations in an important publisher's list, and the role of translation in the consecration and accumulation of 'literary capital.' The issue reveals a rich pattern of transnational interaction, and the social and economic forces behind it. The 'sociology of literary translation' constitutes the theme of a special issue of IASL, edited by Norbert Bachleitner and Michaela Wolf (2004). In their introduction, the editors identify as key elements in the field of literary translation the international position of languages, the role of institutions and translators, the geographical centres of translation and distribution, and the heteronomic conditions of production. They argue that the macro conditions of political, religious, and ideological contexts should also be considered. More recently, chapters in Constructing a Sociology of Translation (edited by Michaela Wolf and Alexandra Fukari) present a theoretical framework for the development of a sociology of translation, ranging from the question of what actually constitutes a translator to general systems theories. ${ }^{4}$ Johan Heilbron and Gisèle Sapiro's contribution to this book sets a sociological view of translation against the hermeneutic approach directed at textual meaning and interpretation, on the one hand, and the reductive economic approach, with its exclusive focus on the book market, on the other. ${ }^{5}$ Like Casanova, but also like de $S w a n^{6}$, they situate transnational transfer within the political, economic, and cultural power relations amongst national and linguistic communities. The 'centrality' of a language is mainly determined by the groups' size and cultural acclaim ('cultural capital').

${ }^{2}$ Joseph Jurt, Das literarische Feld. Das Konzept Pierre Bourdieus in Theorie und Praxis, Darmstadt: Wissenschaftliche Buchgesellschaft, 1995.

3 See Pascale Casanova, The World Republic of Letters, Cambridge MA: Harvard UP, 2004 (French original 1999).

${ }^{4}$ Michaela Wolf \& Alexandra Fukari (Eds.), Constructing a Sociology of Translation, Amsterdam, Philadelphia: John Benjamins, 2007.

5 Johan Heilbron \& Gisèle Sapiro, "Outline for a sociology of translation. Current issues and future prospects", in: Wolf/Fukari (see note 4), p. 93-107.

"See Abram de Swaan, Words of the World. The Global Language Systern, Cambridge: Polity Press, 2001. 
In addition to the general social forces sketched above, individuals with firm opinions and ideals may also have a decisive impact on the course of events, although their initiatives are actually often stimulated by and embedded in social, economical, or political circumstances. Bernard Lahire argues in favour of a sociological approach that reconciles general societal processes with an interest in individual differences. ${ }^{7}$ It is often due to individuals, in interaction with general circumstances, that new opportunities and changes are created. We may therefore think of individual writers, publishers, translators, or critics as pioneers and innovators in the interliterary field. The studies by Andringa and Levie in this issue show, for instance, that the ruptures caused by revolution, war, or depression forced individuals to leave their countries and develop initiatives abroad, and this involved the transference of acquired cultural capital into a new environment.

Even-Zohar's polysystem theory offers a different, and equally fruitful, theoretical perspective on translation and reception studies. ${ }^{8}$ It depicts literary fields as a system of subsystems, consisting of groups of actors sharing cultural repertoires, such as literary canons, literary values, and 'tools' for performing literary communication. The polysystem approach avoids drawing sharp boundaries and prefers to stress, instead, dynamic interaction and changing hierarchical relationships. Those dynamics arise either from within the subsystems, - when literary works move from the periphery towards the centre of attention and recognition and the other way around - or from the interaction between subsystems that are advancing towards a more central position within a polysystem. These subsystems can belong to different cultural or language areas. Polysystem theory offers a heuristic instrument to the description and analysis of transformation and change. It is not an alternative to the concepts developed by Bourdieu and his followers, but can be complementary to their approach, as it pays more attention to specific repertoires or works of art; Bourdieu's concepts focus on general social drives and energies.

The disciplines of history of culture and book history, finally, are highly valuable for insights into intercultural exchange. These disciplines provide us with data on the material and immaterial conditions for the printing, production, distribution and trade of books, and the role of media as well as of cultural mediators. The migration of books or, indeed, entire oeuvres is largely determined by factors such as the publishers' acquisition of foreign oeuvres, international copyright legislation, and the role of translators. Such studies sometimes reach out to other parts of the literary field, for example to educational programmes, cultural

\footnotetext{
7 Bernard Lahire, "From the Habitus to an Individual Heritage of Dispositions. Towards a Sociology at the Level of the Individual," in Poetics 31, 2003, p. 329-355.

${ }^{8}$ The outline and main concepts of polysystem theory can be found in Itamar Even-Zohar, "Polysystem Theory. The 'Literary System'. The Position of Translated Litcrature within the Literary Polysystem," in Poetics Today 11/1, 1990, p. 9-51.
} 
societies, and reading circles, thereby anchoring literary communication within society at large and tying in with the field of the sociology of culture.

The developments in these young, interdisciplinary approaches to transnational reception processes may offer a new perspective on national literary histories. Traditionally, literary histories focused on national literatures, taking into account developments abroad solely as factors of context and influence. Foreign literatures are principally not considered to be part of national literatures, even if there is a long history of translation or reading in foreign languages, or if foreign works have clearly set the standard for national works. Selections, once made, are usually reproduced over a long time; hence, even the most recent national literary histories tend to exclude foreign literature from the national literary culture of which they have become part. As Joseph Jurt writes in his contribution: "Der Nachweis, dass nationale Kulturen zu wesentlichen Teilen auf (reinterpretierten oder reformulierten) Beiträgen von Fremd- und Nachbarkulturen beruhen, gräbt jeder substantialistischen oder gar nationalistischen Argumentation das Wasser ab." $\mathrm{He}$ emphasises, however, that a given culture should not exclusively be regarded as determined by foreign influence ("fremdbestimmt").

Most contributions to this issue have emerged from a conference held in 2007, in The Hague. ${ }^{9}$ Its aim was to bring together scholars from the fields mentioned, in order to discuss the various approaches to transnational reception processes. Participants were asked to present a theoretical and/or methodological concept in connection with field theory, polysystem theory, or concepts from book history and translation studies, and illustrate it with a case study. In preparing this special issue, the original discussion papers were thoroughly rewritten or even replaced, although the initial 'briefing' remained unaltered. Hence, the following articles offer a broad spectrum of concepts and approaches to case studies from different areas and periods.

Armin Paul Frank exemplifies that a long career of research into transnational reception can lead to a treasure house of distinctive insights. His contribution starts by pinpointing some basic definitions, thereby fine-tuning the key-notions of the conference. By speaking of 'transfer,' we had intended to allow for a wider domain than exchange by translation solely. Frank defines transfer as 'all kinds of literary and cultural border crossing: the concrete importation respectively exportation of literary and other cultural goods, but also the transportation of ideas and experiences by immigrants or travellers.' His transfer concept comprises forms of transformation, such as translation, and also involves the kind of resonance ef-

9 The conference 'Transfer and Integration: Foreign Literatures in National Contexts' took place at the Huygens Institure at The Hague in late August. It was organized by Els Andringa (Utrecht), Ton van Kalmthout (Den Haag), Sophie Levie (Nijmegen) and Ton Naaijkens (Utrecht). The conference was supported by the Royal Dutch Academy of Science (KNAW), the Huygens Institute, the Research Institute of History and Culture (OGC) Utrecht, the Institute for Historical, Literary and Cultural Studies (HLCS) Nijmegen, and the Dutch Graduate School of Literary Studies (OSL). 
fectuated by allusions to foreign literature in a national literature and the incorporation of cross-national references into new works. A range of factors, situations, and activities come into view. Frank's typology of nine basic interliterary situations captures most of the case studies presented in this issue. It encompasses both the hierarchical situation, in which a more established, highly esteemed literature sets the standard for a new and still developing one, and the situation of literatures with equal cultural weight in competition with one another. The nine situations also include the difficult existence of linguistic enclaves cut off from the language of origin and the situation of Diaspora literatures which, often disseminated across different locations, lack a geographical centre. Frank's differentiations have the merit of laying bare the sheer complexity of the key-concepts in the title of this issue. What, for example, is integration? Does it mean that a foreign literature is included in a new culture as part of it, thereby contributing to its pluriformity? Or does it mean that it is absorbed by a target literature because it is (re)used and inscribed (Frank: "Einschreibung") into new products? Is foreign literature recognized as different and acknowledged as having an identity of its own? Or does it mean that it can serve as an example for a developing new culture? And what, actually, is 'national' and what 'foreign'? Is this determined by language, by geographical distance, by cultural difference, by national-political boundaries, or by a different esprit? Frank's own study on the connections between a British-English and an emerging American-English literature concerns two geographically and nationally distinct societies sharing the same language; he traces the different trends in association and dissociation with a 'mother literature.'

The 'minor' language and literature of the Netherlands is characterised by a complex history of relationships with neighbouring countries. A history of being subsumed by different empires, and the proximity of French, English, and German cultures imply that cultural interaction was subject to changes in a neighbouring country's socio-political situation or cultural dominance. It was also affected by varying degrees of awareness of a national identity. Our special issue contains four studies which show aspects of different interliterary situations in relation to the Netherlands.

In the early modern period, literary works were produced in at least two languages within a single country: Latin and the vernacular. Jan Bloemendal examines the implications of this practice in two simultaneous (poly)systems: in the case of translations and adaptations of Elckerlijc into Latin and English. He argues that this Dutch morality play, written at the end of the fifteenth century, became part of the history of world literature precisely in these translation processes. Discussing the different stages of Elckerlijc in the sixteenth and seventeenth centuries, Bloemendal investigates the notion of 'national' and 'foreign,' from both a linguistic and a geographical point of view. His contribution shows that the mobility of texts, with all kinds of culturally motivated adaptations, can be traced to 
the beginning of the early modern period. Of course, there was mobility earlier as well.

Els Andringa's contribution presents an example of the Diaspora literature written by writers who fled from Germany after the National Socialists assumed power in 1933. Some writers, critics, and publishers fled to neighbouring countries, where they set up facilities to continue their occupations and activities within the foreign culture and language. The Netherlands became a centre of exile publication and distribution. The works published were not just (mainly) written in German; many of them focused on the history and situation of German Jews, which added a particular dimension to this situation. The reception of these works in the Netherlands was enhanced by the Dutch-Jewish literary subsystem, which had already existed and sometimes served as a foil for comparison. Andringa's article explores this situation and attempts to provide some answers to the question why both Dutch-Jewish and German-Jewish literature published in the Netherlands during the 1930s has failed to achieve recognition in Dutch literary histories.

France has long been the cultural example for the Dutch elite. Mathijs Sanders recapitulates the history of a Netherlands-France Society, founded in the Netherlands during the First World War with the objective of counteracting the dominant image in the French press that the Netherlands was pro-German. The Society stimulated the exchange and circulation of art, literature, and science between the two nations with a range of activities, chiefly publications, lectures, translations, and editions. Sanders focuses on the discursive practice of the Society's two key figures, and he analyses the repertoire of rhetoric strategies and topoi that served their continuous attempts to underscore the cultural and spiritual affinities between the two nations.

From the end of the eighteenth century onwards, Dutch literary culture has confronted a growing stream of texts in translation. For a long time, however, teachers and officials in the educational system considered the study of literature in translation a real threat to Dutch national identity. Ton van Kalmthout addresses the relationship between teaching literature and translation practices between 1880 and 1940. A heterogeneous and reduced literary repertoire, strongly defined in national terms (German, French, English and, above all, Dutch), was offered in school curricula, due to a prohibition on reading in school foreign books in translation. School education therefore did not contribute to the internationalisation of Dutch reading habits; this was primarily furthered by the efforts and idealism of several publishing houses, foremost among them the Wereldbibliotheek and Meulenhoff. Publishing foreign literature in translation proved to be one of the main strategies for educating the Dutch reading public.

Susanne Janssen examines trends in the degree, direction, and diversity of newspaper coverage of foreign literature in four countries: France, Germany, the Netherlands, and the United States. Her results indicate that linguistic and cultural 'centrality' is an important factor in the literary world-system. The waning in- 
fluence of French language and literature, for example, was balanced by the rapid growth in French newspaper coverage of literature from abroad. Whereas the other studies in this issue make use of discourse analysis or historical reconstructions based on individual documents or simple statistics, Janssen's study deploys quantitative measures, which involve large quantitites of data for a systematic cross-national comparison covering changes over time.

Joseph Jurt presents another complicated interliterary situation, by examining the case of Switzerland. Its multilingual society represents a problematic national literary identity. Authors writing in German are easily identified with the German language (the language of both Germany and Austria), whereas works in French tend to be included in the French domain. This situation is mirrored by geography, as writing and publishing are oriented towards the big publishing houses in the respective cultural centres abroad. It also means that works written in one language must be translated into the other if a wider audience is to be reached, even within the same country. Jurt's case study of the avant-garde author Jean-Luc Benoziglio illustrates, in the light of the conditions in the respective literary fields, the different reception patterns of the original French works and their German translations.

Sophie Levie examines the consequences of immigration in the academic reception of Vladimir Nabokov's work, with a focus on recent developments. Nabokov fled from Russia to Europe in 1919, and again from France to the United States in 1940. This double exile forms a central theme in his prose. In the course of his career he translated his former Russian prose works into English, thereby reconceptualising and redirecting his early work to fit his status as a transnational writer. Nabokov's conscious 'playing' with his own interliterary position illustrates how authors themselves can merge two literary (poly)systems in order to strengthen their position in world literature at large. Levie points out that the community of Nabokov researchers show a growing interest in these self-directed processes of transition and adaptation, which in turn reflects the globalisation of their very community.

Norbert Bachleitner's contribution brings us back to the connection between book history and translation studies. His point of departure is Robert Darnton's cyclic model of book production and reception, which accounts for their main institutions and mediators. Bachleitner elaborates on this model by adding agents involved in the introduction, production, and distribution of translated texts: mediators of foreign literature, such as translators and specialized publishers, but also the 'intellectual property regime' which, in the course of the nineteenth century, began to control book transactions by means of copyright agreements. Bachleitner illuminates his model with data from the translation 'industry' in the German speaking countries during the nineteenth century. He exemplifies the social, economic, and cultural constraints with the carcers of individual translators, changing concepts of translation, and the role of (self-)censorship; he illustrates 
their role in the early German translation of Walter Scott and the first translation of Flaubert's Madame Bovary. Detailed comparisons of original and sometimes hilariously translated phrases serve as revealing indicators.

Some of the reviews in this issue of arcadia tie in with our theme, as they deal with books devoted to processes of transnational reception. They include three volumes of the series The Reception of British and Irish authors (see note 1) and studies of the translation and transformation of works by Jane Austen.

Els Andringa

Sophie Levie 